\title{
Competitive interactions shape plant responses to nitrogen fertilization and drought: evidence from a microcosm experiment with Lilium bulbiferum $\mathrm{L}$. and Secale cereale $\mathrm{L}$.
}

\author{
Julia Lütke Schwienhorst • Corinna Pyrlik - Anna Tomberge - Andreas Fichtner (D) \\ David Walmsley (D) - Goddert von Oheimb (iD) - Werner Härdtle (i)
}

Received: 8 August 2021 / Accepted: 3 January 2022 / Published online: 24 January 2022

(C) The Author(s) 2022

\begin{abstract}
Many recent studies have analysed plant species responses to environmental change, but interactive effects of global change drivers and how they are modulated by biotic interactions are still poorly understood. In a mesocosm experiment, we studied the interactive effects of nitrogen $(\mathrm{N})$ fertilization and drought events on plant growth and how these effects are shaped by competitive interactions, using a segetal plant community typical of the lowlands of central Europe (composed of Lilium bulbiferum (segetal species) and Secale cereale (crop species)). We expected that $\mathrm{N}$ fertilization increases the drought sensitivity of Lilium (negative interaction effect), and that these effects are shaped by interspecific
\end{abstract}

Communicated by Robert James Griffin-Nolan.

Supplementary Information The online version contains supplementary material available at https://doi.org/10.1007/ s11258-022-01220-1.

J. Lütke Schwienhorst · A. Fichtner .

D. Walmsley · W. Härdtle $(\square)$

Institute of Ecology, Faculty of Sustainability, Leuphana

University of Lüneburg, Universitätsallee 1,

21335 Lüneburg, Germany

e-mail: haerdtle@uni-lueneburg.de

C. Pyrlik

Auf der Heide 17, 59558 Lippstadt, Germany

A. Tomberge

Uhlandstraße 18, 34119 Kassel, Germany competition with Secale. Secale and Lilium showed opposing responses to $\mathrm{N}$ fertilization (second year of the experiment): Whilst Secale aboveground and belowground biomass almost doubled with $\mathrm{N}$ fertilization, Lilium aboveground and belowground biomass showed no response or decreased, respectively, providing Secale with a competitive advantage. Lilium aboveground tissue dieback (as a proxy for growth vigour) was $22 \%$ in $\mathrm{N}$ and $35 \%$ in drought treatments (control: 6\%), but reached $91 \%$ when combining these treatments. Increasing Lilium tissue dieback was strongly related to decreasing belowground (root) biomass, caused by both negative direct effects of combined treatments $(\mathrm{N}$ fertilization + drought), and negative indirect effects acting via treatment-induced increase in Secale biomass. Our results demonstrate that competitive interactions can shape the effects of global change drivers on plant growth. This knowledge in turn could be important for plant species

G. von Oheimb

Institute of General Ecology and Environmental Protection, Technische Universität Dresden, Pienner Str.

7, 01735 Tharandt, Germany

G. von Oheimb

German Centre of Integrative Biodiversity Research

(iDiv) Halle-Jena-Leipzig, Deutscher Platz 5E,

04103 Leipzig, Germany 
conservation, particularly in the face of ongoing shifts in environmental conditions.

Keywords $\delta^{13} \mathrm{C}$ signature - Global change · Interspecific competition - Root:shoot ratio - Segetal plants

\section{Introduction}

Climate change and ecosystem eutrophication with nitrogen $(\mathrm{N})$ are two major components of global change, with far-reaching consequences for biodiversity and ecosystem functioning on global and local scales (Sala et al. 2000; Valliere et al. 2017; IPBES 2019). Recent climate projections predict rising mean annual temperatures, changing precipitation regimes, and shifts in the frequency and magnitude of extreme weather events, including more severe summer droughts (IPCC 2013). The deposition of reactive nitrogen compounds has tripled on a global scale since the beginning of the industrialization in the nineteenth century (Galloway et al. 2004). As a consequence, both climate change and $\mathrm{N}$ fertilization may influence plant species coexistence due to effects on ecophysiological processes controlling plant growth rates and competitive interactions (Fowler et al. 2013; Ferrarini et al. 2017; Baattrup-Pedersen et al. 2018; Rowland et al. 2021).

Drought events affect ecosystem functions such as primary production and carbon allocation, but also the functional composition of plant communities due to diversity-specific trait spectra and concomitant differences in morpho-physiological adaptations of species to drought stress (Zandalinas et al. 2018). Recent studies have demonstrated that drought resistance of plants is strongly controlled by traits that are directly associated with physiological processes (stomatal conductance, hydraulic pressure, carboxylation capacity), rather than morphological traits (Rowland et al. 2021). These findings suggest that drought events might act as a filter favouring species that better tolerate or cope with hydraulic stress, which in turn provides a competitive advantage during periods of water shortage. Ecosystem eutrophication with $\mathrm{N}$ is a further important driver of global change (Galloway et al. 2004; Fowler et al. 2013). Since N is a (co)limiting nutrient in many ecosystems, $\mathrm{N}$ fertilization affects primary productivity and interactions between plant species, but also their sensitivity to abiotic and biotic stressors such as drought, frost events, and herbivory (Bobbink et al. 2010). In many cases, $\mathrm{N}$ fertilization causes a shift in plant species composition to the benefit of fast growing and highly productive species, which in turn outcompete the less productive ones (Bobbink et al. 2010; Friedrich et al. 2011). In this way, $\mathrm{N}$ fertilization constitutes one of the most substantial drivers of current global biodiversity loss (Drewniak and Ginzalez-Meler 2017; Valliere et al. 2017).

Whilst $\mathrm{N}$ fertilization has affected ecosystem processes over the past decades, the impact of climate change is expected to increase in importance over the course of this century (IPCC 2013). This means that ecosystems with already altered $\mathrm{N}$ cycles and levels are now subject to climate shifts, and both factors will continue to act upon ecosystems in the coming decades (Greaver et al. 2016). Thus, alteration of $\mathrm{N}$ cycles via eutrophication may in turn alter the response of ecosystems to climate change. Combinations of abiotic stressors, however, often are nonadditive, and thus cannot be inferred from approaches in which environmental factors were assessed singularly (Dieleman et al. 2012; Xu et al. 2018). For example, it is conceivable that plant responses to climate change may interact with $\mathrm{N}$ fertilization, likely due to fertilization effects on plant traits such as height growth or root:shoot ratios (Dziedek et al. 2016a). Increasing above-ground investments are often accompanied by increasing transpiration rates and thus by increasing evaporative demands, whereas lowered below-ground investments may constrain water uptake and thus a plant's water supply (Meyer-Grünefeldt et al. 2015a, b). In this way, N fertilization has the potential to increase the drought sensitivity of plants, particularly when $\mathrm{N}$ fertilization predates drought events (Turner and Henry 2009; Meyer-Grünefeldt et al. 2015a; Dziedek et al. 2016a). Moreover, nitrogen concentrations are increasing over the years, whereas drought events often occur as sporadic extreme events. Thus, drought events represent a further environmental stressor on top of chronic changes in the nutritional status of an ecosystem.

In addition to the effects of abiotic environmental changes, biotic factors such as competitive interactions also may shape species and community responses to global change. Competitive interactions 
are often mediated by plant traits that determine a species' competitive performance in a given plant community (Guittar et al. 2016; Xu et al. 2018). For example, field experiments of Valliere et al. (2017) showed that experimental $\mathrm{N}$ additions exacerbated the loss of native shrub species in a Mediterranean shrubland and accelerated the encroachment of nonnatives, especially annual grasses, all of which strongly benefited from increasing $\mathrm{N}$ availability. An important trait supporting the competitiveness of (nonnative) grasses over shrubs was that grass species were characterized by high biomass investments to shallow roots (particularly under increasing $\mathrm{N}$ availability), which rapidly decreased soil moisture in the upper soil profile to the detriment of deeper-rooted perennials (Wood et al. 2006; Valliere et al. 2017). Contrasting traits in terms of $\mathrm{N}$ use may thus codetermine plant community responses to global change (Mendoza et al. 2016; Ferrarini et al. 2017).

To improve our understanding of interactive effects of co-occurring drivers of global change, the present study analysed combined effects of $\mathrm{N}$ fertilization and drought events on plant growth and how these effects are mediated by interspecific competition of plant species.

We performed a 2-year mesocosm experiment to compare the effects of drought events on $\mathrm{N}$-fertilized and non-fertilized plants, taking a segetal plant community typical of the lowlands of central Europe. This plant community often consists of only two species, Lilium bulbiferum L. as the segetal plant species and Secale cereale L. as crop species (Sclerantho annui-Arnoseridetum minimae; Ellenberg and Leuschner 2010; Bos 2012). Referring to this community we considered Lilium bulbiferum L. as the target species in our experiment. Nowadays, Lilium bulbiferum is highly endangered due to continuous habitat loss, management intensification, and more frequent drought events (Ludwig and Schnittler 1996; van Elsen et al. 2006; Bos 2012; Meyer et al. 2013, 2015). Current conservation measures aim at a long-term protection of remnant Lilium bulbiferum population by establishing rye fields that are subject to organic farming, using a typical lowland rye breed adapted to sandy and low-nutrient soils (so-called Champagne rye; Bos 2012). Since Lilium bulbiferum populations are still decreasing, we selected this plant community as an example to scrutinize the effects of currently acting global change drivers in relation to competitive interactions of both plant species.

Our goal behind this experimental setting was to analyse how $\mathrm{N}$-fertilized plants respond to subsequent drought events, simulating field conditions in which plant communities with already altered $\mathrm{N}$ levels (due to fertilizer application or atmospheric $\mathrm{N}$ deposition) are nowadays subject to climate change. Specifically, we wanted to know how combined effects of $\mathrm{N}$ fertilization and drought events affect growth of Lilium bulbiferum and how these effects are modulated by interspecific competition with the crop species Secale cereale. Growth responses were measured in terms morphological traits (aboveground and belowground biomass, root:shoot ratios, and tissue dieback) and physiological traits (aboveground and belowground tissue $\delta^{13} \mathrm{C}$ signatures and $\mathrm{C}: \mathrm{N}$ ratios). We hypothesized that (i) $\mathrm{N}$ fertilization increases the drought sensitivity (i.e. relative shifts in trait values in response to treatments, such as decreasing biomass productivity and tissue $\mathrm{C}: \mathrm{N}$ ratios, and increasing tissue dieback and $\delta^{13} \mathrm{C}$ signatures) of Lilium bulbiferum (i.e. non-additive response), and that (ii) Lilium bulbiferum responses to treatments are shaped by competitive interactions with the crop species Secale cereale.

\section{Methods}

\section{Experimental design}

Our mesocosm experiment was conducted in a greenhouse in the experimental garden of the University of Lüneburg (Lüneburg, Germany, $53^{\circ} 14^{\prime} 23.8^{\prime \prime} \mathrm{N}$, $\left.10^{\circ} 24^{\prime} 45.5^{\prime \prime} \mathrm{E}\right)$. The mesocosm pots used were $0.3 \times 0.3 \times 0.3 \mathrm{~m}^{3}$ in dimension (volume: $27 \mathrm{~L}$ ) and were filled with soil material originating from the natural habitat (i.e. low-intensively managed arable fields) of Lilium bulbiferum in the river Elbe valley in Lower Saxony $\left(53^{\circ} 10^{\prime} 08^{\prime \prime} \mathrm{N}, 11^{\circ} 00^{\prime} 04^{\prime \prime} \mathrm{E}\right)$ to simulate a high degree of natural site conditions (soil characteristics of the upper mineral soil: texture: slightly loamy sand, $\mathrm{pH}_{(\mathrm{H} 2 \mathrm{O})}$ : 4.8$)$.

In October 2015 five bulbils of Lilium bulbiferum (sampled from the leaf axils from natural populations and at the same sites where soil samples were taken; henceforth referred to as Lilium) and 20 seeds of winter rye (Secale cereale; seed farm Hof Tütsberg, 
Schneverdingen, Germany; henceforth referred to as Secale) were introduced into each mesocosm. The ratio of five Lilium bulbils and 20 Secale seeds was chosen to simulate the ratio of these species as they appear in the real segetal plant community (Bos 2012). Four Lilium bulbils were placed in the corners (corner distance $8-10 \mathrm{~cm}$ ) and one in the centre of the mesocosms. Secale seeds were sown in two rows with $2.5 \mathrm{~cm}$ between-seed distance and a sowing row distance of $12.5 \mathrm{~cm}$ (corresponding to the sowing density used in the arable fields; seed row distance to the mesocosm's edge was $8.7 \mathrm{~cm}$ at each side; planting design see Fig. 1). This design was used to simulate growth conditions of Lilium in its natural habitat (i.e. in a rye field). We established a total of 40 mesocosms, 20 of which were randomly assigned to two treatments in March 2016 (start of growing season): control and $\mathrm{N}$ fertilization treatment (henceforth referred to as control and $\mathrm{N}$ treatment, respectively). In the $\mathrm{N}$ treatment, $\mathrm{N}$ was applied as $\mathrm{NH}_{4} \mathrm{NO}_{3}$ dissolved in deionized water and at 11 occasions from March to July 2016 ( $0.2 \mathrm{~L}$ solution per occasion). The total amount of $\mathrm{N}$ applied was equivalent to

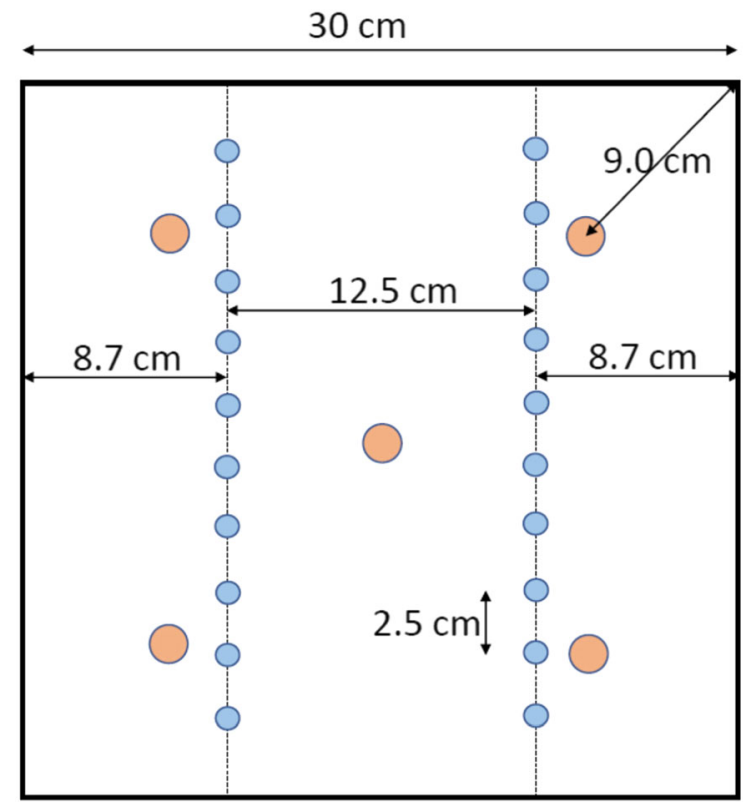

Fig. 1 Planting design of the mesocosm experiment. Mesocosm pots were $30 \mathrm{~cm} \times 30 \mathrm{~cm}$ in width (black frame). In total, 20 seeds of Secale cereale (blue circles) and five bulbils of Lilium bulbiferum (orange circles) were planted in the first year of the experiment (and Secale cereale seeds again in the second year of the experiment; further explanations see text)
$40 \mathrm{~kg} \mathrm{ha}^{-1}$ year $^{-1}$, which corresponds to both current maximum $\mathrm{N}$ deposition rates in the lowlands of central Europe (Vivanco et al. 2018) or restricted N fertilizer application rates in arable fields subject to plant species protection targets under organic farming (Kuhn 2017). Non-fertilized mesocosms received $0.2 \mathrm{~L}$ deionized water at the same time when $\mathrm{N}$ solutions were applied. In August 2016, all plants were harvested by clipping stalks above the soil surface to imitate a late-summer field harvesting. The belowground biomass (and particularly the bulbs of Lilium) remained untouched during harvest (and all plants survived and regrew in the second year of the experiment; see below).

In October 2016, 20 Secale seeds were again introduced into each mesocosm, following the procedure applied in 2015 (since Secale cereale is an annual species). In March 2017, mesocosms were subject to a total of four treatments (i.e. $n=10$ per treatment). To this end, 10 out of the 20 control mesocosms from 2016 were randomly assigned to a control, and the remaining 10 mesocosms to a drought treatment (henceforth referred to as $\mathrm{D}$ treatment). In addition, 10 out of the $20 \mathrm{~N}$ treated mesocosms from 2016 were randomly assigned to an $\mathrm{N}$ treatment (i.e. continuation of the $\mathrm{N}$ fertilization), and the remaining 10 mesocosms to an $\mathrm{N}+\mathrm{D}$ treatment (i.e. a combination of $\mathrm{N}$ and drought treatments, henceforth referred to as ND treatment). $\mathrm{N}$ treatments were performed in the same way as in 2016, but $\mathrm{N}$ was applied on 8 occasions between March and June to allow for a timely start of the subsequent drought treatments. In the D and ND treatments, mesocosms were subject to a drought period (no watering of plants) starting in the mid of June and lasting for four weeks. Drought treatments resulted in a decrease of the mesocosms' soil water content by $31.7 \%$ (mean percentage loss compared to field capacity at the end of the drought period; mean amount of soil water in the mesocosm pots under field capacity: $2.7 \mathrm{~L}$, mean amount of soil water after the drought treatment: $1.84 \mathrm{~L}$; water loss in relation to field capacity: $31.7 \%$ ). Water loss was quantified by comparing pre- and post-treatment mesocosm weights. With the exception of the drought period, mesocosms were regularly watered (both years) and the soil moisture content was kept close to field capacity (about $25 \%$ of the total soil pore volume). All pots were randomly relocated every two weeks to avoid position effects (both years). The mean 
temperature in the greenhouse was $16.5^{\circ} \mathrm{C}$ and $17.2{ }^{\circ} \mathrm{C}$, and the mean relative humidity was $67.6 \%$ and $69.4 \%$ in the first (2016) and second year (2017) of the experiment, respectively (means from the beginning of March to the end of August).

Plant harvest and measurements of response variables

In 2016, the following response variables were quantified: aboveground biomass dry weight of Secale and Lilium after harvest. In 2017, the experiment was completed in August and the following response variables quantified: aboveground and belowground biomass dry weight of Secale and Lilium, necrotic/ dead aboveground tissue of Lilium, C:N ratio and $\delta^{13} \mathrm{C}$ signatures of the aboveground biomass, coarse roots, and bulbs of Lilium (for the relevance of the response variables measured in the context of climate change and fertilization experiments see Dziedek et al 2016b; Meyer-Grünefeldt et al. 2015b). Aboveground biomass dry weight was determined after harvest of all aboveground plant parts of Secale and Lilium (clipping stalks above the soil surface). Belowground biomass was quantified by carefully wet sieving roots until soil residues were removed as far as possible. Subsequently, roots were towelled down and separated for each of the two species using a stereomicroscope. For Lilium, belowground biomass (produced by the plants over the 2 years of the experiment) was differentiated for bulbs, coarse, and fine roots, considering a root diameter of $2 \mathrm{~mm}$ as threshold between fine and coarse roots (Rose et al. 2009). As the separation and cleaning procedure of Secale roots (produced by the plants in 2017) and Lilium fine roots was very laborious, we quantified these variables for a subset of five randomly selected mesocosms per treatment only (i.e. $n=5$ per treatment).

All biomass samples were dried to a constant weight at $40{ }^{\circ} \mathrm{C}$ and afterwards the dry weight was quantified (for Secale in g per mesocosm, for Lilium in $\mathrm{g}$ per individual per mesocosm, calculated as mean of the respective five individuals). For both species we quantified root:shoot ratios (RSR; $n=5$ per treatment in 2017), defined as the quotient of aboveground biomass dry weight and (coarse + fine) root biomass dry weight (Friedrich et al. 2011). At the end of the D treatment, the amount of necrotic/dead aboveground tissue (henceforth referred to as 'tissue dieback') of each Lilium individual was visually estimated (in \% necrotic/damaged tissue per plant individual; i.e. leaf cells were damaged or dead, recognizable by a corresponding discolouration (brownish or black) and tissue dieback per microcosm was quantified as the mean of individual responses (using the relative importance of each individual in terms of its contribution to total tissue dieback of all Lilium plants per mesocosm).

Analyses of morphological responses were complemented by the analyses of physiological responses for Lilium (tissue $\mathrm{C}: \mathrm{N}$ ratios and $\delta^{13} \mathrm{C}$ signatures, only for living tissue and for 2017). To this end, biomass samples of the aboveground biomass, coarse roots, and bulbs were ground in a centrifugal mill (ZM 200, Retsch, Haan, Germany) and re-dried at $40{ }^{\circ} \mathrm{C}$ for 3 days. Tissue $\mathrm{C}: \mathrm{N}$ ratios and $\delta^{13} \mathrm{C}$ signatures were measured using a continuous flow elemental analyzerisotope mass spectrometer (vario EL cube, Elementar, Hanau, Germany, coupled to an Isoprime Isotope-ratio mass spectrometer, Isoprime Ltd., Cheadle Hulme, UK). Isotope signatures were presented in the delta notation (in \%o) as a relative deviation from an international standard (PeeDee Belemnite). The relative precision of repeated analyses of an International Atomic Energy Agency-standard (IAEA-CH-3) was $\pm 0.1 \%$.

\section{Statistics}

As a first step we assigned all responses variables measured to a group of morphological and a group of physiological response variables and tested by means of a MANOVA, whether grouped variables were differently affected by treatments (N, D, ND) and Secale aboveground biomass (multivariate response; Quinn and Keough 2002; Crawley 2007). Grouped morphological variables were as follows: Lilium aboveground biomass, Lilium belowground biomass, Lilium root:shoot ratio, and amount of necrotic/dead tissue. Grouped physiological variables were: Lilium aboveground biomass $\delta^{13} \mathrm{C}$ signature, Lilium coarse root ${ }^{13} \mathrm{C}$ signature, Lilium aboveground biomass $\mathrm{C}: \mathrm{N}$ ratio, and Lilium coarse root $\mathrm{C}: \mathrm{N}$ ratio (data from the second year of the experiment). These response variables were selected in correspondence to those considered in the linear models (see below). We transformed the variables 'tissue dieback' and 'Lilium aboveground biomass' (log- and square root- 
transformation, respectively) to meet model assumptions (Crawley 2007).

Second, we used linear models to explore the effects of experimental treatments and of interspecific competition on morphological and physiological response variables of Lilium (data for 2017; using the morphological and physiological response variables mentioned above). In the full model we considered the treatments N, D, ND, and Secale aboveground biomass as explanatory variables and included all possible two-way interaction terms between treatments and Secale aboveground biomass (to test for possible treatment effects acting upon Lilium via shifts in Secale aboveground biomass, i.e. treatment-induced shifts in the interspecific competition between Lilium and Secale). We omitted the variable Secale belowground biomass from the models due to its high positive correlation with Secale aboveground biomass $(r=0.90)$. The variables 'tissue dieback' and 'Secale aboveground biomass' were log-transformed to meet model assumptions (Crawley 2007). Determination of the most parsimonious model was based on the Akaike information criterion (AIC), and the model with the smallest AIC was chosen as the best-fitting model (Burnham and Anderson 2002; Tredennick et al. 2021). Model assumptions were visually checked and confirmed according to Zuur et al. (2009).

Third, we explored the multiple relationships (direct and indirect effects) between $\mathrm{N}$ fertilization, drought, interspecific competition, and target species performance using structural equation models (SEMs; applied to second-year data). Specifically, we tested whether (i) treatments (N, D, ND) have a direct effect on growth (total biomass) and RSR (biomass allocation) of Lilium, but also (ii) an indirect effect related to treatment-induced shifts in Secale's biomass and thus competitive Secale-Lilium interactions, which in turn could mediate treatment effects on Lilium growth and performance (tissue dieback). Thus, we were interested in the following pathways: (i) N, D, ND effects on Secale biomass, (ii) N, D, ND and Secale biomass effects on Lilium biomass, (iii) N, D, ND, and Lilium biomass effects on Lilium RSR ratios, and (iv) effects of Secale biomass, Lilium biomass, and Lilium RSR on Lilium tissue dieback (SEM model). In this way, SEM path analyses were considered to complement outcomes of linear models (ideally, our design should have included monocultures of Lilium and Secale in response to treatments, but this would have tripled the number of microcosms and was not feasible due to logistical constraints). Tissue dieback was used as an indicator for Lilium's growth vigour and competitive performance (Dziedek et al. 2016b), and the aboveground biomass of Secale was used as a proxy for its competitive strength, assuming that an increase in Secale's aboveground biomass will lead to a reduction in the competitive ability of Lilium. To support the interpretation of Lilium growth responses to treatments and Secale biomass, we also calculated SEMs in which the variable "total Lilium biomass" was replaced by "Lilium aboveground biomass" and "Lilium belowground biomass" (see Supplementary Material Fig. S1 and S2, respectively). Treatments (N, $\mathrm{D}, \mathrm{ND})$ were coded as binary variables $(0=$ no treatment, 1 = treatment) and were treated as numeric predictors in the model (Rosseel 2012). Tissue dieback was log-transformed to improve linearity with other variables in the model (Grace et al. 2010). Model fit statistics were evaluated following Kline (2014): Chisquare test with associated $P$-value $(P>0.05$ indicates that sample and observed covariance matrices are statistically not different), standardized root mean square residual (SRMR) and comparative fit index (CFI). Low values of SRMR $(<0.10)$ and high values of CFI ( $\geq 0.90)$ indicate a good model fit. All analyses were conducted in $\mathrm{R}$ (version 3.3.1) using the package lavaan (Rosseel 2012).

\section{Results}

Treatment effects on Secale biomass

Secale aboveground and belowground biomass increased in $\mathrm{N}$-fertilized mesocosms $(P<0.05$; Table 1). In the $\mathrm{N}$ treatments, aboveground biomass almost doubled in comparison to the control (second year). In contrast, the D treatment had no effect on the Secale aboveground and belowground biomass. In addition, Secale root:shoot ratios remained unaffected across treatments (Table 1).

Treatment effects on morphological response variables of Lilium

Grouped morphological response variables of Lilium significantly responded to the $\mathrm{D}$ treatment $(P=0.036)$, the ND treatment $(P<0.001)$, and to 
Table 1 Treatment effects on morphological and physiological response variables (first year: means of $n=20$; second year: means of $n=5$ for Secale/Lilium (fine) root/total belowground biomass and root:shoot ratios, and $n=10$ for all other variables, $\pm 1 \mathrm{SE}$ in brackets)

\begin{tabular}{|c|c|c|c|c|c|c|c|c|}
\hline \multirow{2}{*}{$\begin{array}{l}\text { Treatment } \\
\text { Response variables }\end{array}$} & \multicolumn{2}{|l|}{ Control } & \multicolumn{2}{|l|}{$\mathrm{N}$} & \multicolumn{2}{|l|}{$\mathrm{D}$} & \multicolumn{2}{|l|}{ ND } \\
\hline & Mean & SE & Mean & SE & Mean & SE & Mean & SE \\
\hline \multicolumn{9}{|l|}{ First year } \\
\hline $\begin{array}{l}\text { Secale aboveground biomass } \\
\text { (g per pot) }\end{array}$ & $12.51^{\mathrm{a}}$ & $(0.39)$ & $16.90^{\mathrm{b}}$ & $(0.62)$ & & & & \\
\hline $\begin{array}{l}\text { Lilium aboveground biomass } \\
\text { (g per plant) }\end{array}$ & $0.015^{\mathrm{a}}$ & $(0.001)$ & $0.022^{\mathrm{b}}$ & $(0.002)$ & & & & \\
\hline Second year & & & & & & & & \\
\hline $\begin{array}{l}\text { Secale aboveground biomass } \\
\text { (g per pot) }\end{array}$ & $11.39^{\mathrm{a}}$ & $(1.18)$ & $22.19^{\mathrm{b}}$ & $(2.02)$ & $9.28^{\mathrm{a}}$ & $(0.67)$ & $20.80^{\mathrm{b}}$ & $(1.47)$ \\
\hline $\begin{array}{l}\text { Secale belowground biomass } \\
\text { (g per pot) }\end{array}$ & $8.59^{\mathrm{ab}}$ & $(1.09)$ & $15.07^{\mathrm{c}}$ & $(2.98)$ & $4.48^{\mathrm{a}}$ & $(0.58)$ & $11.97^{\mathrm{bc}}$ & $(1.17)$ \\
\hline Secale root:shoot ratio & $0.64^{\mathrm{a}}$ & $(0.06)$ & $0.71^{\mathrm{a}}$ & $(0.14)$ & $0.46^{\mathrm{a}}$ & $(0.02)$ & $0.51^{\mathrm{a}}$ & $(0.04)$ \\
\hline Lilium necrotic/dead tissue $(\%)$ & $5.78^{\mathrm{a}}$ & $(2.34)$ & $21.62^{\mathrm{ab}}$ & $(7.17)$ & $35.48^{\mathrm{b}}$ & $(8.11)$ & $91.00^{\mathrm{c}}$ & $(8.15)$ \\
\hline $\begin{array}{l}\text { Lilium aboveground biomass } \\
\text { (g per plant) }\end{array}$ & $0.57^{\mathrm{a}}$ & $(0.08)$ & $0.55^{\mathrm{a}}$ & $(0.09)$ & $0.59^{\mathrm{a}}$ & $(0.03)$ & $0.39^{\mathrm{a}}$ & $(0.05)$ \\
\hline $\begin{array}{l}\text { Lilium total belowground biomass (g per } \\
\text { plant) }\end{array}$ & $10.49^{\mathrm{a}}$ & $(1.82)$ & $6.58^{\mathrm{ab}}$ & $(2.02)$ & $7.36^{\mathrm{ab}}$ & $(0.35)$ & $3.42^{\mathrm{b}}$ & $(0.85)$ \\
\hline $\begin{array}{l}\text { Lilium fine root biomass } \\
\text { (g per plant) }\end{array}$ & $3.82^{\mathrm{a}}$ & $(0.79)$ & $1.58^{\mathrm{b}}$ & $(0.62)$ & $1.28^{\mathrm{b}}$ & $(0.12)$ & $0.81^{\mathrm{b}}$ & $(0.17)$ \\
\hline Lilium coarse root biomass (g per plant) & $2.15^{\mathrm{a}}$ & $(0.50)$ & $0.72^{\mathrm{b}}$ & $(0.13)$ & $0.95^{\mathrm{b}}$ & $(0.08)$ & $0.52^{\mathrm{b}}$ & $(0.08)$ \\
\hline Lilium bulb biomass (g per plant) & $5.12^{\mathrm{a}}$ & $(0.75)$ & $4.20^{\mathrm{ab}}$ & $(0.73)$ & $5.44^{\mathrm{a}}$ & $(0.26)$ & $2.38^{\mathrm{b}}$ & $(0.40)$ \\
\hline Lilium root:shoot ratio & $12.05^{\mathrm{a}}$ & $(2.69)$ & $3.97^{\mathrm{b}}$ & $(0.45)$ & $4.19^{\mathrm{b}}$ & $(0.21)$ & $3.45^{\mathrm{b}}$ & $(1.00)$ \\
\hline Lilium aboveground biomass $\mathrm{C}: \mathrm{N}$ ratio & $23.28^{\mathrm{a}}$ & $(1.73)$ & $23.37^{\mathrm{a}}$ & $(1.89)$ & $49.14^{\mathrm{b}}$ & $(1.05)$ & $39.56^{\mathrm{b}}$ & $(1.21)$ \\
\hline Lilium coarse root $\mathrm{C}: \mathrm{N}$ ratio & $50.14^{\mathrm{a}}$ & $(7.32)$ & $42.31^{\mathrm{b}}$ & $(2.10)$ & $48.45^{\mathrm{a}}$ & $(4.96)$ & $38.46^{\mathrm{b}}$ & $(1.46)$ \\
\hline Lilium bulb $\mathrm{C}: \mathrm{N}$ ratio & $68.77^{\mathrm{a}}$ & $(1.30)$ & $43.20^{\mathrm{b}}$ & $(0.51)$ & $84.00^{\mathrm{a}}$ & $(4.60)$ & $38.91^{\mathrm{b}}$ & $(2.19)$ \\
\hline $\begin{array}{l}\text { Lilium aboveground biomass } \\
\delta^{13} \mathrm{C} \text { signature }(\% \mathrm{o})\end{array}$ & $-30.14^{\mathrm{a}}$ & $(0.10)$ & $-29.48^{\mathrm{b}}$ & $(0.20)$ & $-29.77^{\mathrm{ab}}$ & $(0.10)$ & $-29.69^{\mathrm{ab}}$ & $(0.17)$ \\
\hline Lilium coarse root $\delta^{13} \mathrm{C}$ signature $(\% 0)$ & $-29.94^{\mathrm{a}}$ & $(0.15)$ & $-29.01^{b}$ & $(0.21)$ & $-28.90^{b}$ & $(0.13)$ & $-29.17^{b}$ & $(0.21)$ \\
\hline Lilium bulb $\delta^{13} \mathrm{C}$ signature (\%) & $-29.94^{\mathrm{a}}$ & $(0.14)$ & $-28.87^{\mathrm{b}}$ & $(0.12)$ & $-29.09^{b}$ & $(0.11)$ & $-29.32^{\mathrm{ab}}$ & $(0.17)$ \\
\hline
\end{tabular}

$\mathrm{D}=$ drought treatment, $\mathrm{N}=$ nitrogen treatment, $\mathrm{ND}=$ combined nitrogen and drought treatment; $\mathrm{DW}=$ dry weight. Lower case letters indicate significant between-treatment differences (first year: ANOVA; second year: Tukey post hoc test; not underlined and underlined lower case letters indicate $P<0.05$ and $P<0.1$, respectively)

Secale aboveground biomass $(P=0.061$; Table 2$)$. In addition, grouped morphological variables were significantly affected by interactions of Secale aboveground biomass with $\mathrm{N}$ and ND treatments $(P=0.020$ and 0.029 , respectively; Table 2).

If single response variables are considered, Lilium aboveground biomass positively responded to $\mathrm{N}$ fertilization in the first year of the experiment (i.e. of one-year old plants; $P<0.05$; Table 1). In the second year, Lilium aboveground biomass was not affected in
$\mathrm{N}$-fertilized mesocosms, and fine and coarse root biomass decreased (i.e. of two-year old plants; Fig. 2a, b). This decrease in belowground biomass was particularly strong in the ND treatment (including biomass of bulbs; by $32 \%$ compared to the control; $P<0.05$; Table 1, Fig. 2b). In addition, Lilium RSR showed a large decrease in $\mathrm{N}$-fertilized mesocosms (by $33 \%$ in the $\mathrm{N}$ and by $29 \%$ in the ND treatment compared to the control; Fig. 2c). Lilium tissue dieback (necrotic/dead aboveground tissue) was 
Table 2 Results of the MANOVA summarizing effects of treatments (N, D, ND) and Secale aboveground biomass on grouped morphological (a) and physiological (b) response variables (multivariate response) of Lilium

\begin{tabular}{|c|c|c|c|c|}
\hline & \multicolumn{2}{|c|}{$\begin{array}{l}\text { (a) Grouped morphological } \\
\text { response variables }\end{array}$} & \multicolumn{2}{|c|}{$\begin{array}{l}\text { (b) Grouped physiological } \\
\text { response variables }\end{array}$} \\
\hline & $F$-value & $P$-value & $F$-value & $P$-value \\
\hline $\mathrm{N}$ & 1.851 & 0.196 & 5.724 & 0.002 \\
\hline $\mathrm{D}$ & 3.945 & 0.036 & 12.721 & $<0.001$ \\
\hline ND & 16.094 & $<0.001$ & 20.349 & $<0.001$ \\
\hline Secale above & 3.207 & 0.061 & 2.744 & 0.048 \\
\hline $\mathrm{N}^{*}$ Secale_above & 4.791 & 0.020 & 1.070 & 0.390 \\
\hline $\mathrm{D} *$ Secale above & 0.810 & 0.547 & 0.480 & 0.750 \\
\hline ND*Secale above & 4.242 & 0.029 & 0.042 & 0.996 \\
\hline
\end{tabular}

The response variables selected correspond to those considered in the linear models (Table 3). Grouped morphological variables: Lilium aboveground biomass, Lilium belowground biomass, Lilium root:shoot ratio, amount of necrotic/dead tissue; grouped physiological variables: Lilium aboveground biomass $\delta^{13} \mathrm{C}$ signature, Lilium coarse root $\delta^{13} \mathrm{C}$ signature, Lilium aboveground biomass $\mathrm{C}: \mathrm{N}$ ratio, Lilium coarse root $\mathrm{C}: \mathrm{N}$ ratio, (data of the second year of the experiment). Abbreviations of treatments: $\mathrm{N}=$ nitrogen treatment, $\mathrm{D}=$ drought treatment, $\mathrm{ND}=$ combined nitrogen and drought treatment, Secale above = Secale aboveground biomass; significant effects and marginally significant effects $(P<0.05$ and $P<0.1$, respectively) are indicated in bold

particularly high in the ND treatment $(91 \%$; Table 1 ; Fig. 2d).

The D treatment (performed in the second year of the experiment) had no effect on the aboveground biomass of Lilium, but significantly decreased Lilium fine and coarse root biomass and thus RSRs (Fig. 2b, c). However, the sole effect of drought on both Lilium biomass and tissue dieback was comparatively low compared to the ND treatment (Table 1; Fig. 2).

Treatment effects on physiological response variables of Lilium

Grouped physiological response variables were affected by all treatments (N, D, ND; $P=0.002$ and $<0.001$, respectively) and Secale aboveground biomass $(P=0.048)$, but we found no significant interaction terms (Table 2). Lilium aboveground biomass $\mathrm{C}: \mathrm{N}$ ratios were not affected in the $\mathrm{N}$ treatment $(P>0.05)$, but showed a remarkable increase in the drought treatments (by $211 \%$ compared to the control; $P<0.05$; Table 1; second year data). In contrast, $\mathrm{N}$ fertilization significantly lowered tissue $\mathrm{C}: \mathrm{N}$ ratios of coarse roots and bulbs.

Tissue $\delta^{13} \mathrm{C}$ signatures of Lilium (above- and belowground) increased across treatments, but this trend was less pronounced for the aboveground tissue in the D and ND treatments (Table 1). Between- treatment differences of tissue $\delta^{13} \mathrm{C}$ signatures were not significant.

Treatments effects in relation to Secale-Lilium competition

Results of the linear models showed that Lilium aboveground biomass decreased with increasing Secale aboveground biomass across treatments (slope estimate: $-0.485 ; P<0.001$; Table 3 ; second-year data). Moreover, we found significant interactions between Secale aboveground biomass and the $\mathrm{N}$ treatment, which increased Lilium tissue dieback (slope estimate: 3.166; $P=0.045$; Table 3; Fig. 3a, b), and decreased Lilium belowground biomass (slope estimate: $-9.953 ; P=0.029$; Table 3) and Lilium RSRs (slope estimate: $-20.231 ; P<0.001$; Table 3). Lilium RSRs were also negatively affected by interactions between Secale aboveground biomass and the $\mathrm{D}$ and ND treatments (slope estimate: -20.920 ; $P=0.003$, slope estimate: $-15.945 ; \quad P=0.012$, respectively; Table 3). $\mathrm{N}$ fertilization thus exacerbated Lilium tissue dieback and reduced Lilium RSRs via increasing aboveground biomass of Secale.

For tissue C:N ratios and $\delta^{13} \mathrm{C}$ signatures, only $\mathrm{N}$, $\mathrm{D}$, and ND treatments were significant predictors in the linear models, and all two-way interactions were excluded in the most parsimonious models (with the 


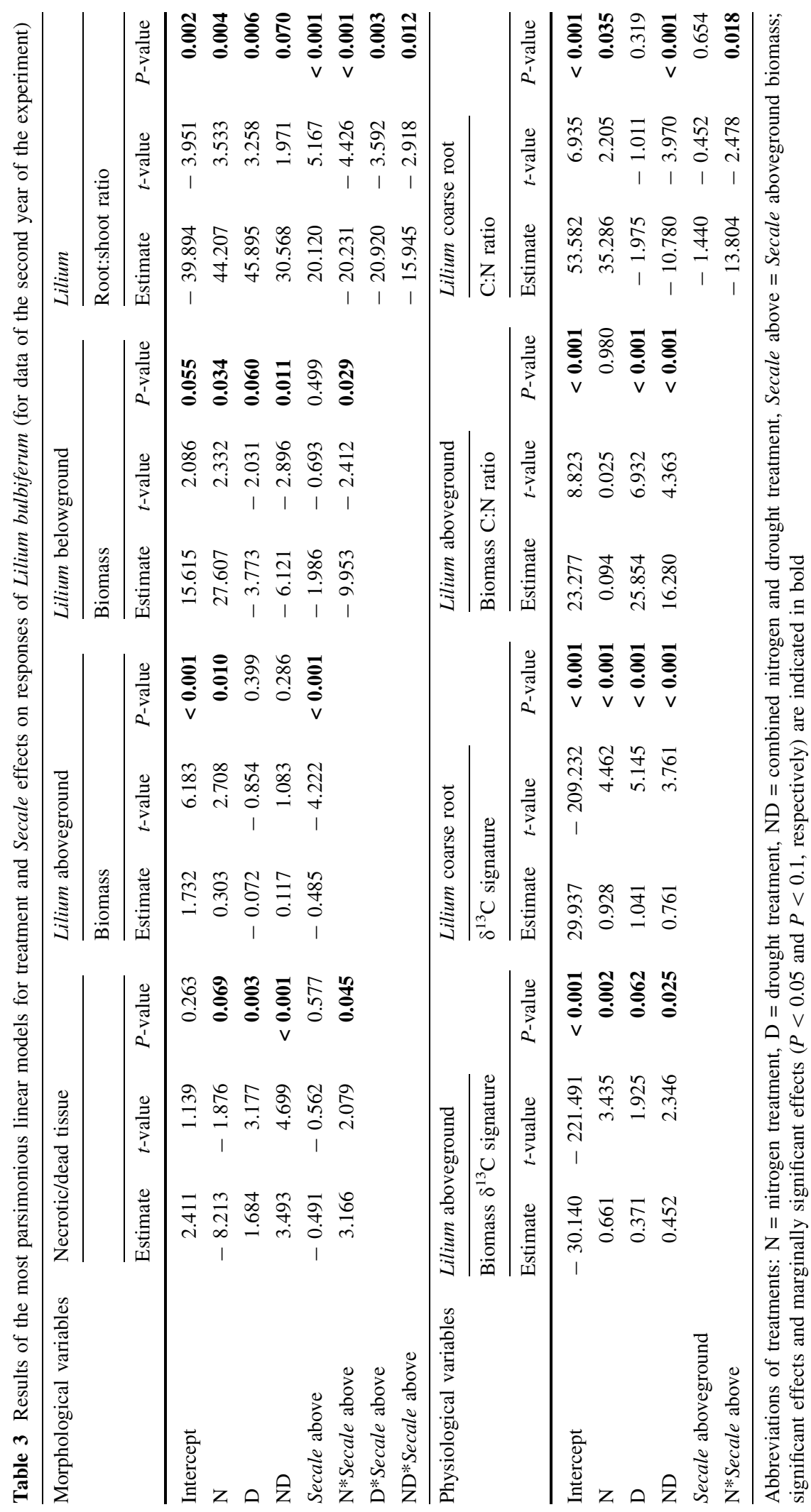


(a)

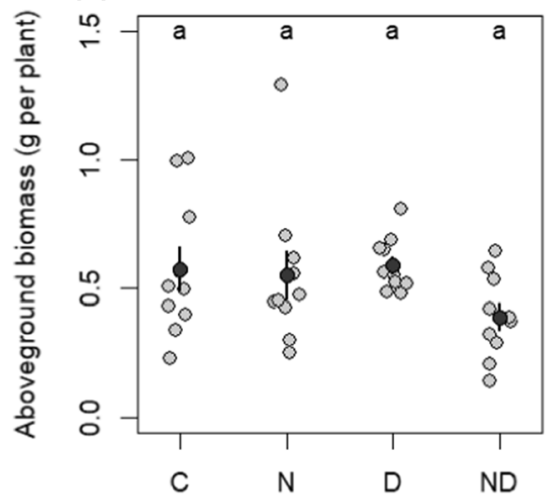

(c)

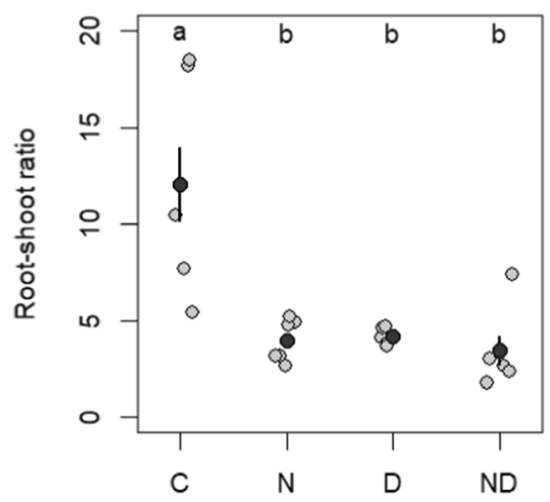

Fig. 2 Morphological responses of Lilium bulbiferum to treatments (C: control, N: nitrogen, D: drought, ND: nitrogen and drought). Lilium responses are shown in terms of a aboveground biomass, $\mathbf{b}$ belowground biomass, $\mathbf{c}$ root:shoot ratios, and $\mathbf{d}$ necrotic/dead tissue. Black points indicate the observed means and error bars correspond to the standard errors.

exception of Lilium root $\mathrm{C}: \mathrm{N}$ ratios, for which we found a significant $\mathrm{N} \times$ Secale aboveground biomass interaction; slope estimate: $-13.804 ; \quad P=0.018$; Table 3).

The SEM provided a good fit to the data $\left(P\left(\chi^{2}\right)=0.118 ; \quad\right.$ CFI $=0.956 ; \quad$ SRMR $=0.052 ;$ Fig. 4). D and ND treatments strongly reduced total Lilium biomass $\left(R^{2}: 0.60\right)$ and $\operatorname{RSR}\left(R^{2}: 0.65\right.$; direct treatment effect), which in turn enhanced the plants' tissue dieback $\left(R^{2}: 0.60\right)$. In contrast, $\mathrm{N}$ and ND treatments positively affected Secale aboveground biomass, which in turn had negative effects on Lilium belowground biomass (indirect treatment effect; $P=-0.73$ ). In this way, $\mathrm{N}$ and ND treatments enhanced the tissue dieback of Lilium due to competitive interactions between Secale and Lilium. SEMs (b)

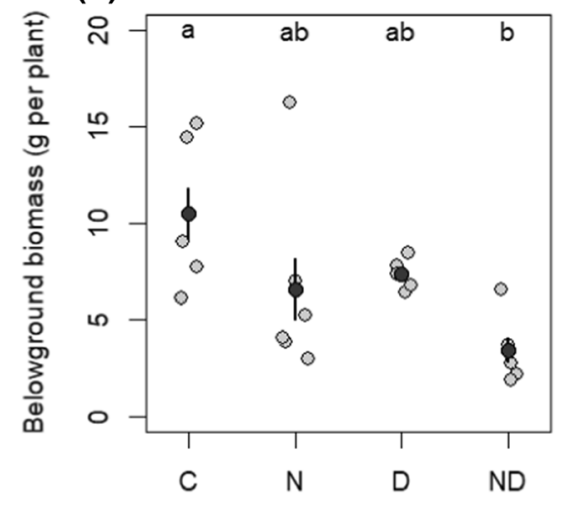

(d)

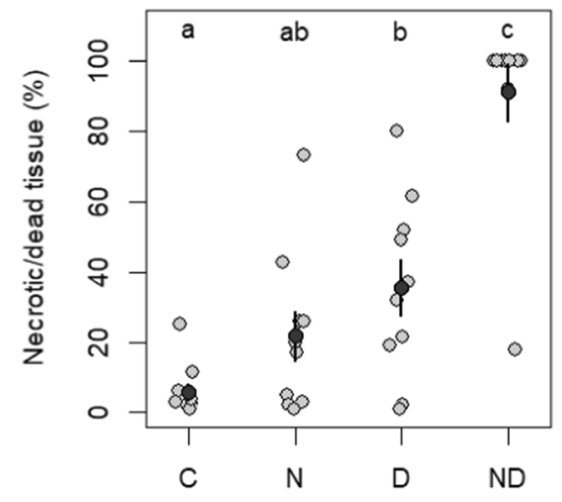

Observed values (grey points) were slightly jittered to improve visibility. Different letters indicating significant differences amongst treatments are based on log-transformed values for the variable "Necrotic/dead tissue" (Tukey post hoc test $P_{\text {adj.- }}$ $<0.05)$. The values presented in the figure are non-transformed for a better comprehensibility

provided the same findings (in terms of the significance of pathways) when the variable "total Lilium biomass" was replaced by "Lilium aboveground biomass" or "Lilium belowground biomass" (supplementary material, Fig. S1 and S2).

\section{Discussion}

Our findings confirm our first hypothesis that $\mathrm{N}$ fertilization has the potential to significantly increase the drought sensitivity of Lilium plants, in this instance mainly due to effects on morphological attributes of the target species such as biomass productivity or traits such as RSR (indicating aboveground/belowground allocation patterns). Increasing sensitivity (in terms of 


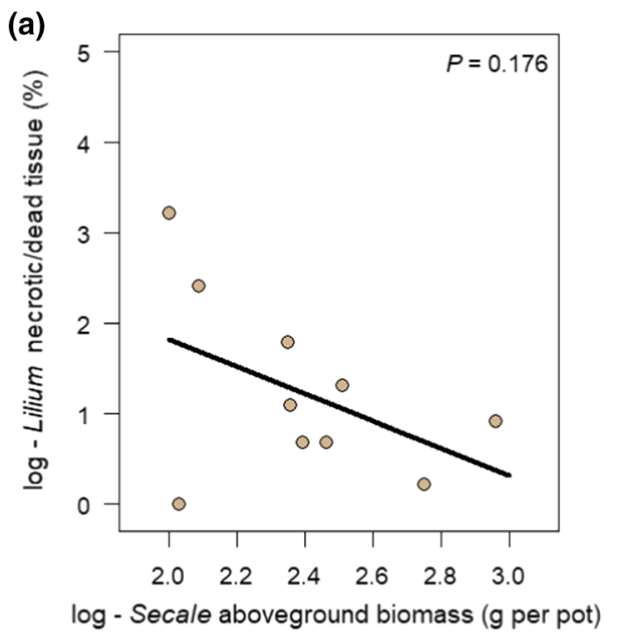

Fig. 3 Relationships between necrotic/dead tissue of Lilium bulbiferum and aboveground biomass of Secale cereale a without (control) and $\mathbf{b}$ with nitrogen fertilization ( $\mathrm{N}$ treatment). Regression lines correspond to a linear model fit

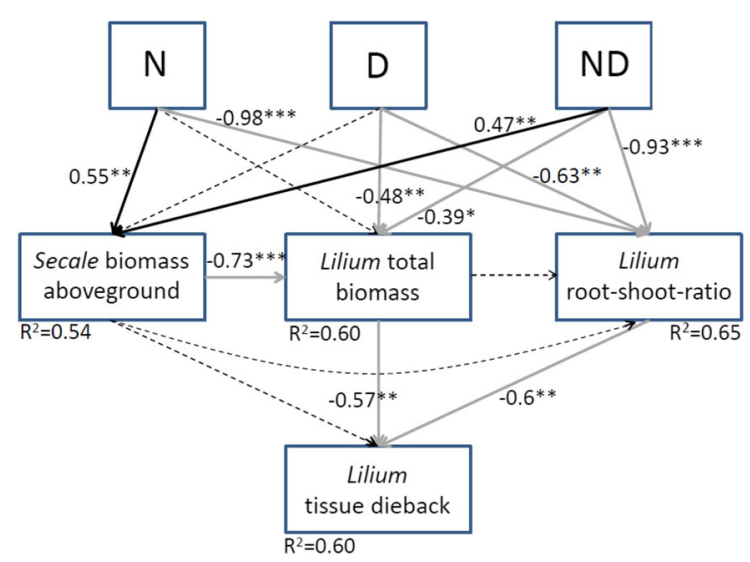

Fig. 4 Structural equation model visualizing treatment effects (N, D, ND) on Secale aboveground biomass, total Lilium biomass, and Lilium root:shoot ratios, with the latter two in turn affecting tissue dieback of Lilium (data from the second year of the experiment). Black and grey lines denote positive and negative significant relationships, respectively, and dashed lines non-significant relationships. The numbers at arrows are standardized regression coefficients (i.e. the magnitude of the coefficients is proportional to the effect size). Asterisks denote a significant pathway in the model $(* P<0.05$, $* * P<0.01$, $* * * P<0.001)$. The proportion of variance explained $\left(R^{2}\right)$ appears alongside the boxes for endogenous variables. Abbreviations: $N$ nitrogen treatment, $D$ drought treatment, $N D$ combination of nitrogen and drought treatment

relative changes in response variables in relation to treatments) was reflected by a distinct decline of the belowground biomass of Lilium and a concomitant

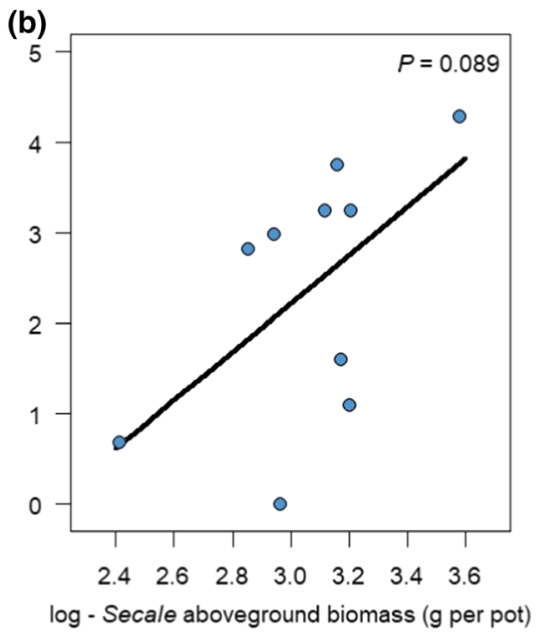

and dots indicate observed values. Note that the $\mathrm{N}$ treatmentrelated shift in the slopes of the two straight lines indicates a significant interaction between the $\mathrm{N}$ treatment and the aboveground biomass of Secale cereale (cf. Table 3)

increase in tissue dieback in mesocosms subject to the ND treatment. Moreover, our study demonstrates that this strong dieback is partly driven by the combined effects of $\mathrm{N}$ fertilization and drought, but also by the effects of increasing biomass productivity of Secale as a result of $\mathrm{N}$ fertilization. Thus, direct (i.e. treatment) and indirect (i.e. competitive interactions) effects explain Lilium responses to shifts in abiotic conditions.

Non-additive effects of $\mathrm{N}$ fertilization and drought on Lilium growth can be explained by two mechanisms. First, N fertilization may increase a plant's aboveground investments in relation to belowground biomass formation, resulting in decreasing RSR (according to the 'resource optimization hypothesis'; Ågren and Franklin 2003; cf. Table 3 for N effects on RSR, $P=0.004$ ). Decreasing RSR, as a result of $\mathrm{N}$ fertilization, has been shown for several plant species and across different life forms (Friedrich et al. 2012; Meyer-Grünefeldt et al. 2015b; Dziedek et al. 2016a). Lowered RSR may increase a plant's evaporative demands (per unit root biomass) and transpiration costs, making it more prone to drought stress (Gordon et al. 1999; Meyer-Grünefeldt et al. 2015a). Second, N fertilization often alters root morphology in that roots show higher extension rates but lower tissue density (Eissenstat 1991; Mendoza et al. 2016; Wang et al. 2018). As a result, root mortality increases when soils start to dry out (Meier and Leuschner 2008; Noguchi 
et al. 2013). In our experiment, the dieback of fine roots could therefore have contributed to the lowered fine root biomass in $\mathrm{N}$-fertilized mesocosms (Dziedek et al. 2016b). In this context it is important to note that Lilium dieback in mesocosms subject to a sole D treatment was low compared to the ND treatment, indicating a higher drought resistance of non-fertilized plants and amplifying (non-additive) negative effects of combined N and D treatments. Strong effects of ND treatments on overall plant growth and performance are also reflected by significant responses of both grouped morphological and physiological variables (MANOVA).

However, as stated in our second hypothesis, adverse effects of $\mathrm{N}$ fertilization on Lilium growth were also related to fertilization-induced shifts in the interspecific competition with Secale. This interpretation is supported by findings of the linear models and SEM, according to which $\mathrm{N}$ and ND treatments strongly fostered Secale biomass productivity, which in turn strengthened its competitive superiority over Lilium. Importantly, Secale and two-year old Lilium exhibited opposing responses to $\mathrm{N}$ fertilization (i.e. growth benefit vs. no effect or even inhibition, respectively; Mendoza et al. 2016), particularly with regard to the ND treatment, in which about $90 \%$ of the Lilium aboveground tissue necrotized. Although our experimental design did not allow for a clear detection of the mechanisms causing the dieback of Lilium in the ND microcosms, it is likely that both aboveground competition for light and belowground competition (for nutrients and water) contributed to this growth response: On the one hand, increasing Secale aboveground productivity reduced both above- and belowground biomass of Lilium, a mechanism that was fostered by $\mathrm{N}$ fertilization $(\mathrm{N} / \mathrm{ND} \times$ Secale biomass interaction; indicated by both significant multivariate responses of grouped morphological variables (MANOVA) und univariate responses (linear models)). On the other hand, two-year old Lilium plants proved to be the inferior competitor for belowground resources such as $\mathrm{N}$, since its aboveground biomass $\mathrm{C}: \mathrm{N}$ ratios remained unaltered or even increased in the $\mathrm{N}$ and $\mathrm{ND}$ treatment, respectively, indicating that Lilium could not benefit from an increased soil $\mathrm{N}$ availability in $\mathrm{N}$-fertilized mesocosms ( $\mathrm{N}$ accumulation in belowground biomass, indicated by decreasing $\mathrm{C}: \mathrm{N}$ ratios; von Oheimb et al. 2010). The same holds true for belowground resources such as water: In all mesocosms in which Secale developed a high belowground (root) biomass, tissue $\delta^{13} \mathrm{C}$ signatures of Lilium increased significantly. This suggests that Secale also was the superior competitor for water. This interpretation is supported by the finding that tissue $\delta^{13} \mathrm{C}$ signatures of Lilium were more related to Secale belowground biomass than to Lilium RSRs (i.e. ${ }^{13} \mathrm{C}$ discrimination of Lilium seems to be more affected by competition for water than by transpiration rates).

Between-species competitive interactions, however, emerged only in the second year of the experiment (i.e. when Lilium plants were 2 years old), as suggested by between-year comparisons of aboveground biomass responses of both species to $\mathrm{N}$ fertilization. Probably, one-year old Lilium plants were too small to cause such interactions being effective aboveground or belowground (e.g. Lilium aboveground biomass was almost 40-times higher for two-year old compared to 1-year old plants). This finding might also point to some shortcomings of our experiment: Since competitive interactions were observed only over two years, it is conceivable that our findings might be different for longer-term experiments. In addition, indirect effects of global change drivers on plant growth via interspecific interactions und the underlying mechanisms might be better detected, if experiments include monocultures of all plant species typical of a focal plant community. However, interactions effects between $\mathrm{N}$ fertilization and interspecific competition were also found in experiments of Friedrich et al. (2011) and Valliere et al. (2017), but the outcomes of our experiment suggest that impacts of co-occurring drivers of global change (here: $\mathrm{N}$ fertilization and drought) are mediated by interspecific competition.

Contrary to decreasing RSR of Lilium under N fertilization, Secale RSR remained unchanged, indicating balanced aboveground-belowground investments even under high $\mathrm{N}$ availability (and contrasting the prediction of the resource optimization hypothesis). This strategy seems to be typical of many grass species, providing them a competitive advantage for belowground resources over other species or life forms, particularly under increasing $\mathrm{N}$ availability (Wood et al. 2006; Friedrich et al. 2011; Mendoza et al. 2016).

Our findings that both 'direct' (abiotic) and 'indirect' (biotic) pathways may influence plant responses 
to environmental changes might have implications for the long-term preservation of plant diversity, particularly in N-limited environments. Many target species of conservation measures may suffer from direct and non-additive effects of $\mathrm{N}$ fertilization and drought events. These drivers might act via abiotic and biotic interactions, and in turn often are responsible for the encroachment of non-target species (e.g. grasses) in protected environments (Phoenix et al. 2012; Henning et al. 2017; Valliere et al. 2017). In this context, mitigation strategies need to counteract (airborne) $\mathrm{N}$ inputs (e.g. by means of biomass or soil removal) in order to achieve balanced ecosystem $\mathrm{N}$ budgets in the long term.

Author contributions JLS, AF, GvO, and WH conceived and designed the experiment. JLS, CP, and AT performed the experiment. JLS, CP, AT, AF, DW, and WH analysed the data. $\mathrm{AF}, \mathrm{DW}, \mathrm{GvO}$, and $\mathrm{WH}$ wrote the manuscript, with significant contributions of all other authors. All authors read and approved the final manuscript.

Funding Open Access funding enabled and organized by Projekt DEAL. This study was funded by the German Federal Environmental Foundation, Osnabrück, Germany (DBU; Grant number: AZ20015/361).

Data availability All data will be available in the "Dryad Digital Repository" after manuscript acceptance.

Code availability Not applicable.

\section{Declarations}

Conflict of interest The authors have no conflicts of interest to declare that are relevant to the content of this article.

Ethical approval Not applicable.

Consent to participate Not applicable.

Consent for publication Not applicable.

Open Access This article is licensed under a Creative Commons Attribution 4.0 International License, which permits use, sharing, adaptation, distribution and reproduction in any medium or format, as long as you give appropriate credit to the original author(s) and the source, provide a link to the Creative Commons licence, and indicate if changes were made. The images or other third party material in this article are included in the article's Creative Commons licence, unless indicated otherwise in a credit line to the material. If material is not included in the article's Creative Commons licence and your intended use is not permitted by statutory regulation or exceeds the permitted use, you will need to obtain permission directly from the copyright holder. To view a copy of this licence, visit http://creativecommons.org/licenses/by/4.0/.

\section{References}

Ågren GI, Franklin O (2003) Root:shoot ratios, optimization and nitrogen productivity. Ann Bot 92:795-800. https://doi. org/10.1093/aob/mcg203

Baattrup-Pedersen A, Garssen A, Gothe E, Hoffmann CC, Oddershede A, Riis T, van Bodegom PM, Larsen SE, Soons M (2018) Structural and functional responses of plant communities to climate change-mediated alterations in the hydrology of riparian areas in temperate Europe. Ecol Evol 8:4120-4135. https://doi.org/10.1002/ece3.3973

Bobbink R, Hicks K, Galloway J, Spranger T, Alkemade R, Ashmore M, Bustamante M, Cinderby S, Davidson E, Dentener F, Emmett B, Erisman JW, Fenn M, Gilliam F, Nordin A, Pardo L, De Vries W (2010) Global assessment of nitrogen deposition effects on terrestrial plant diversity: a synthesis. Ecol Appl 20:30-59. https://doi.org/10.1890/ 08-1140.1

Bos F (2012) Lilium bulbiferum L. subsp. croceum (Chaic) Arcang., the Orange Lily, a special plant of lowland NW Europe. Floriculture Ornamental Biotech 6:53-62

Burnham KP, Anderson DR (2002) Model selection and multimodel inference: a practical information-theoretic approach, 2nd edn. Springer, New York

Crawley MJ (2007) The R book. Wiley, Chichester

Dieleman WIJ, Vicca S, Dijkstra FA, Hagedorn F, Hovenden MJ, Larsen KS, Morgan JA, Volder A, Beier C, Dukes JS, King J, Leuzinger S, Linder S, Luo YQ, Oren R, de Angelis P, Tingey D, Hoosbeek MR, Janssens IA (2012) Simple additive effects are rare: a quantitative review of plant biomass and soil process responses to combined manipulations of $\mathrm{CO}_{2}$ and temperature. Glob Change Biol 18:2681-2693. https://doi.org/10.1111/j.1365-2486.2012. 02745.x

Drewniak B, Gonzalez-Meler MA (2017) Earth system model needs for including the interactive representation of nitrogen deposition and drought effects on forested ecosystems. Forests. https://doi.org/10.3390/f8080267

Dziedek C, Härdtle W, von Oheimb G, Fichtner A (2016a) Nitrogen addition enhances drought sensitivity of young deciduous tree species. Front Plant Sci. https://doi.org/10. 3389/fpls.2016.01100

Dziedek C, von Oheimb G, Calvo L, Fichtner A, Kriebitzsch WU, Marcos E, Pitz WT, Härdtle W (2016b) Does excess nitrogen supply increase the drought sensitivity of European beech (Fagus sylvatica L.) seedlings? Plant Ecol 217:393-405. https://doi.org/10.1007/s11258-016-0581-1

Eissenstat DM (1991) On the relationship between specific root length and the rate of rote proliferation-a field-study using Citrus rootstocks. New Phytol 118:63-68. https:// doi.org/10.1111/j.1469-8137.1991.tb00565.x

Ellenberg H, Leuschner C (2010) Vegetation Mitteleuropas mit den Alpen. Ulmer, Stuttgart

Ferrarini A, Alatalo JM, Gervasoni D, Foggi B (2017) Exploring the compass of potential changes induced by climate 
warming in plant communities. Ecol Complex 29:1-9. https://doi.org/10.1016/j.ecocom.2016.11.003

Fowler D, Coyle M, Skiba U, Sutton MA, Cape JN, Reis S, Sheppard LJ, Jenkins A, Grizzetti B, Galloway JN, Vitousek P, Leach A, Bouwman AF, Butterbach-Bahl K, Dentener F, Stevenson D, Amann M, Voss M (2013) The global nitrogen cycle in the twenty-first century. Philos Trans R Soc B-Biol Sci. https://doi.org/10.1098/rstb.2013. 0164

Friedrich U, von Oheimb G, Dziedek C, Kriebitzsch WU, Selbmann K, Härdtle W (2011) Mechanisms of purple moor-grass (Molinia caerulea) encroachment in dry heathland ecosystems with chronic nitrogen inputs. Environ Pollut 159:3553-3559. https://doi.org/10.1016/j. envpol.2011.08.010

Friedrich U, von Oheimb G, Kriebitzsch WU, Schlesselmann K, Weber MS, Härdtle W (2012) Nitrogen deposition increases susceptibility to drought-experimental evidence with the perennial grass Molinia caerulea (L.) Moench. Plant Soil 353:59-71. https://doi.org/10.1007/ s11104-011-1008-3

Galloway JN, Dentener FJ, Capone DG, Boyer EW, Howarth RW, Seitzinger SP, Asner GP, Cleveland CC, Green PA, Holland EA, Karl DM, Michaels AF, Porter JH, Townsend AR, Vorosmarty CJ (2004) Nitrogen cycles: past, present, and future. Biogeochemistry 70:153-226. https://doi.org/ 10.1007/s10533-004-0370-0

Gordon C, Woodin SJ, Alexander IJ, Mullins CE (1999) Effects of increased temperature, drought and nitrogen supply on two upland perennials of contrasting functional type: Calluna vulgaris and Pteridium aquilinum. New Phytol 142:243-258. https://doi.org/10.1046/j.1365-2435.1999. 00012.x

Grace JB, Anderson TM, Olff H, Scheiner SM (2010) On the specification of structural equation models for ecological systems. Ecol Monogr 80:67-87. https://doi.org/10.1890/ 09-0464.1

Greaver TL, Clark CM, Compton JE, Vallano D, Talhelm AF, Weaver CP, Band LE, Baron JS, Davidson EA, Tague CL, Felker-Quinn E, Lynch JA, Herrick JD, Liu L, Goodale CL, Novak KJ, Haeuber RA (2016) Key ecological responses to nitrogen are altered by climate change. Nat Clim Change 6:836-843. https://doi.org/10.1038/nclimate3088

Guittar J, Goldberg D, Klanderud K, Telford RJ, Vandvik V (2016) Can trait patterns along gradients predict plant community responses to climate change? Ecology 97:2791-2801. https://doi.org/10.1002/ecy.1500

Henning K, Lorenz A, von Oheimb G, Härdtle W, Tischew S (2017) Year-round cattle and horse grazing supports the restoration of abandoned, dry sandy grassland and heathland communities by supressing Calamagrostis epigejos and enhancing species richness. J Nat Conserv 40:120-130. https://doi.org/10.1016/j.jnc.2017.10.009

IPBES - Intergovernmental Science-Policy Platform on Biodiversity and Ecosystem Services (2019) Summary for policymakers of the global assessment report on biodiversity and ecosystem services of the Intergovernmental SciencePolicy Platform on Biodiversity and Ecosystem Services. IPBES secretariat, Bonn

IPCC - Intergovernmental Panel on Climate Change (2013) The physical science basis. Cambridge University Press,
Cambridge, New York, Contribution of working group I to the fifth assessment

Kline RB (2014) Principles and practice of structural equation modeling. Guilford Press, New York

Kuhn T (2017) The revision of the German fertilizer ordinance in 2017 - Discussion paper. University of Bonn, Bonn, Institute for Food and Resource Economics

Ludwig G, Schnittler M (1996) Rote Liste gefährdeter Pflanzen Deutschlands. Schriftenreihe für Vegetationskunde 28. Bundesamt für Naturschutz, Bonn-Bad Godesberg

Meier IC, Leuschner C (2008) Belowground drought response of European beech: fine root biomass and carbon partitioning in 14 mature stands across a precipitation gradient. Glob Change Biol 14:2081-2095. https://doi.org/10.1111/ j.1365-2486.2008.01634.x

Mendoza R, Garcia I, Deplama D, Lopez CF (2016) Competition and growth of a grass-legume mixture fertilised with nitrogen and phosphorus: effect on nutrient acquisition, root morphology and symbiosis with soil microorganisms. Crop Pasture Sci 67:629-640. https://doi.org/10.1071/ cp15257

Meyer S, Wesche K, Krause B, Leuschner C (2013) Dramatic losses of specialist arable plants in Central Germany since the 1950s/60s-a cross-regional analysis. Divers Distrib 19:1175-1187. https://doi.org/10.1111/ddi.12102

Meyer S, Bergmeier E, Becker T, Wesche K, Krause B, Leuschner C (2015) Detecting long-term losses at the plant community level—arable fields in Germany revisited. Appl Veg Sci 18:432-442. https://doi.org/10.1111/avsc. 12168

Meyer-Grünefeldt M, Friedrich U, Klotz M, Von Oheimb G, Härdtle W (2015a) Nitrogen deposition and drought events have non-additive effects on plant growth-evidence from greenhouse experiments. Plant Biosyst 149:424-432. https://doi.org/10.1080/11263504.2013.853699

Meyer-Grünefeldt M, Calvo L, Marcos E, von Oheimb G, Härdtle W (2015b) Impacts of drought and nitrogen addition on Calluna heathlands differ with plant life-history stage. J Ecol 103:1141-1152. https://doi.org/10.1111/ 1365-2745.12446

Noguchi K, Nagakura J, Kaneko S (2013) Biomass and morphology of fine roots of sugi (Cryptomeria japonica) after three years of nitrogen fertilization. Front Plant Sci. https:// doi.org/10.3389/fpls.2013.00347

Phoenix GK, Emmett BA, Britton AJ, Caporn SJM, Dise NB, Helliwell R, Jones L, Leake JR, Leith ID, Sheppard LJ, Sowerby A, Pilkington MG, Rowe EC, Ashmorek MR, Power SA (2012) Impacts of atmospheric nitrogen deposition: responses of multiple plant and soil parameters across contrasting ecosystems in long-term field experiments. Glob Change Biol 18:1197-1215. https://doi.org/ 10.1111/j.1365-2486.2011.02590.x

Quinn GP, Keough MJ (2002) Experimental design and data analysis for biologists. Cambridge University Press, Cambridge

Rose L, Leuschner C, Kockemann B, Buschmann H (2009) Are marginal beech (Fagus sylvatica $\mathrm{L}$.) provenances a source for drought tolerant ecotypes? Eur J for Res 128:335-343. https://doi.org/10.1007/s10342-009-0268-4

Rosseel Y (2012) lavaan: an R package for structural equation modeling. J Stat Softw 48:1-36 
Rowland L, Oliveira RS, Bittencourt PRL, Giles AL, Coughlin I, Costa PD, Domingues T, Ferreira LV, Vasconcelos SS, Junior JAS, Oliveira AAR, da Costa ACL, Meir P, Mencuccini M (2021) Plant traits controlling growth change in response to a drier climate. New Phytol 229:1363-1374. https://doi.org/10.1111/nph.16972

Sala OE, Chapin FS, Armesto JJ, Berlow E, Bloomfield J, Dirzo R, Huber-Sanwald E, Huenneke LF, Jackson RB, Kinzig A, Leemans R, Lodge DM, Mooney HA, Oesterheld M, Poff NL, Sykes MT, Walker BH, Walker M, Wall DH (2000) Biodiversity - global biodiversity scenarios for the year 2100. Science 287:1770-1774. https://doi.org/10. 1126/science. 287.5459 .1770

Tredennick AT, Hooker G, Ellner SP, Adler PB (2021) A practical guide to selecting models for exploration, inference, and prediction in ecology. Ecology 102:e 03336. https://doi.org/10.1002/ecy.3336

Turner MM, Henry HAL (2009) Interactive effects of warming and increased nitrogen deposition on $15 \mathrm{~N}$ tracer retention in a temperate old field: seasonal trends. Glob Change Biol 15:2885-2893. https://doi.org/10.1111/j.1365-2486.2009. 01881.x

Valliere JM, Irvine IC, Santiago L, Allen EB (2017) High N, dry: Experimental nitrogen deposition exacerbates native shrub loss and nonnative plant invasion during extreme drought. Glob Change Biol 23:4333-4345. https://doi.org/ 10.1111/gcb.13694

van Elsen T, Berg M, Drenckhahn D, Dunkel FG, Eggers T, Garve E, Kaiser B, Marquart H, Pilotek D, Rodi D, Wicke G (2006) The Karlstadt position paper for the preservation of arable field plants. J Plant Dis Prot 20:527-533

Venables WN, Ripley BD (2002) Modern applied statistics with $\mathrm{S}, 4$ th edn. Springer, New York

Vivanco MG, Theobald MR, Garcia-Gomez H, Garrido JL, Prank M, Aas W, Adani M, Alyuz U, Andersson C, Bellasio R, Bessagnet B, Bianconi R, Bieser J, Brandt J, Briganti G, Cappelletti A, Curci G, Christensen JH, Colette A, Couvidat F, Cuvelier C, D'Isidoro M, Flemming J, Fraser
A, Geels C, Hansen KM, Hogrefe C, Im U, Jorba O, Kitwiroon N, Manders A, Mircea M, Otero N, Pay MT, Pozzoli L, Solazzo E, Tsyro S, Unal A, Wind P, Galmarini S (2018) Modeled deposition of nitrogen and sulfur in Europe estimated by 14 air quality model systems: evaluation, effects of changes in emissions and implications for habitat protection. Atmos Chem Phys 18:10199-10218. https:// doi.org/10.5194/acp-18-10199-2018

Von Oheimb G, Power SA, Falk K, Friedrich U, Mohamed A, Krug A, Boschatzke N, Härdtle W (2010) N: P ratio and the nature of nutrient limitation in Calluna-dominated heathlands. Ecosystems 13:317-327. https://doi.org/10.1007/ s10021-010-9320-y

Wang WN, Wang Y, Hoch G, Wang ZQ, Gu JC (2018) Linkage of root morphology to anatomy with increasing nitrogen availability in six temperate tree species. Plant Soil 425:189-200. https://doi.org/10.1007/s11104-018-3563-3

Wood YA, Meixner T, Shouse PJ, Allen EB (2006) Altered ecohydrologic response drives native shrub loss under conditions of elevated nitrogen deposition. J Environ Qual 35:76-92. https://doi.org/10.2134/jeq2004.0465

Xu Z, Li MH, Zimmermann NE, Li SP, Li H, Ren H, Sun H, Han X, Jiang Y, Jiang L (2018) Plant functional diversity modulates global environmental change effects on grassland productivity. J Ecol 106:1941-1951. https://doi.org/ 10.1111/1365-2745.12951

Zandalinas SI, Mittler R, Balfagon D, Arbona V, GomezCadenas A (2018) Plant adaptations to the combination of drought and high temperatures. Physiol Plant 162:2-12. https://doi.org/10.1111/ppl.12540

Zuur AF, Ieno EN, Walker NJ, Saveliev AA, Smith GM (2009) Mixed effects models and extensions in ecology with R. Springer, New York

Publisher's Note Springer Nature remains neutral with regard to jurisdictional claims in published maps and institutional affiliations. 